\title{
Commentary
}

\section{Through the Lens of the Sequence}

\author{
Ellen Wright Clayton \\ Center for Genetics and Health Policy, Department of Pediatrics and School of Law, Vanderbilt University, \\ Nashville, Tennessee 37232, USA
}

The completion of the rough draft of the human genome is a scientific feat worthy of celebration. But the media attention that has been devoted to the Human Genome Project demonstrates that most people are not as interested in what the sequence is as in what it means for individuals and for society, for good or for ill. My purpose in writing this essay is to discuss how the project was conducted here in the United States, and some of the implications of knowing the sequence (or more aptly, a sequence).

The Transformative Impact of the Ethical, Legal, and Social Implications (ELSI) Set-Aside

When James Watson declared that the Human Genome Project in the United States would set aside a portion of the funds provided by Congress to examine and attempt to address the ethical, legal, and social implications of this research, he transformed the face of biomedical research in this country. Previously, the scientific enterprise had proceeded largely without reflection, except for the occasional proclamation that research was inherently beneficial or at least valueneutral. People, usually those outside the scientific community, had argued for some time and with increasing intensity that science was in fact situated in a social context, that the questions asked by scientists were shaped by social influences, and that the results of research had social consequences. Many of these commentators were particularly concerned about genetics, influenced both by the enduring dilemmas posed by this discipline and by the unfortunate history of eugenics here and abroad.

Watson was not writing on a clean slate when he made his very public commitment, but he did bring social inquiry within the inner sanctum of science by reaching into the latter's purse. The effect of making a commitment to explore the implications of genome research has been dramatic. This initiative made it much harder for genome scientists to ignore the impact of their work, to say "leave me alone, this is science, which should be pursued solely for its own sake." Of perhaps broader consequence, the question within the rest of biomedicine became not "why should we study what this research means for people?" but rather "why aren't we looking at these potential conse-

E-MAIL ellen.w.clayton@Vanderbilt.Edu; FAX (615) 936-2783. Article and publication are at www.genome.org/cgi/doi/10.1101/ gr. 187801. quences?" (Report of the Joint NIH/DOE Committee 2000). This transformation can be observed in the increased willingness of other federal agencies to fund research that examines how individuals respond to new developments in medicine and in the increased attention paid by these agencies to addressing ethical and social issues.

Some people have argued that the result of setting aside federal funds for this purpose has been the neutralization of social criticism, implying that the critics have been bought. There may be some validity to such accusations-it is hard to bite down hard on the hand that feeds you. But many, and probably most, of the federally funded investigators have worked in good faith, defining the adverse consequences that may attend a greater understanding of genetics, even if only as the first step toward developing strategies to limit these hazards. The debates about genetic privacy and discrimination and the numerous studies of how people respond to genetic testing are just two examples. It is worth noting that plenty of people are still highly critical of genomics, seeing the whole endeavor as one in which the risks far outweigh any potential gains. One need only look to the writings of Jeremy Rifkin (1984) and the uproar over genetically modified foods here and especially abroad to get a taste of the passion invested in these issues. If the goal of establishing the ELSI Program of the Human Genome Project had been to silence dissent and to permit only uncritical boosterism, which happily it was not, then it would be a spectacular failure. The result of the provision of federal funds for research into the impact of genomics has, instead, been to invite fuller, more informed, and often heated debate.

The Effects of Genomics on Biomedical Research and Health Care Delivery

Apart from the process by which the draft was obtained, what can one say about the social impact of having decoded the human sequence? The first place to look is within biomedicine itself. Everyone would agree that having access to the sequence is a profoundly powerful tool for understanding the pathogenesis of disease. The ability to identify candidate genes, to hypothesize about their function by identifying the family of genes to which they belong, and to identify the same or similar genes in other organisms that permit in vivo experimentation has greatly accel- 
erated the pace of research. As dramatic as these advances have been, however, far more remains to be learned about how genes affect human health. The challenges are even more daunting when one looks beyond the effects of single genes. Little is known about which genes contribute to the appearance of multifactorial, complex phenotypes. Still less is understood about how genes are regulated and about how systems function. Learning how these complex processes operate will require a level of information management that would have been impossible even 10 years ago and for most of us is unimaginable even now. Indeed, the genomics revolution is completely dependent on the other great revolution of our time, the emergence of the information age. To top it all off, as fledgling as our understanding of how genes contribute to disease is, that knowledge far outstrips our ability to prevent or treat these disorders.

The vastness of the not yet known and the gap between understanding and intervention are not unique to genomics. Physicians often know a lot more about what is wrong with a patient than they do about what to do about it. Nonetheless, genomics does present some dilemmas that go beyond those characterizing medicine in general. One of the larger challenges surrounds testing per se, particularly for screening asymptomatic individuals. Physicians do all sorts of tests for diagnostic and predictive purposes. Think, for example, of routine cholesterol screening, Pap smears, and mammograms, to name only a few. Despite the ethical requirement that clinicians discuss options with patients, who then decide for themselves whether or not to proceed, and the well-documented adverse consequences of false-positive test results, such tests typically are performed without a great deal of thought or conversation by the clinician or much consideration by the patient.

Rarely a week goes by without a call in the newspapers or medical journals to screen people for mutations in a newly identified gene. Such proposals to incorporate predictive genetic testing into medical practice, however, usually are not enthusiastically embraced, but rather are met (appropriately) with hesitation and with recommendations for further research to determine how best to proceed. This laudable caution has been observed for a number of tests, including cystic fibrosis carrier testing and testing for mutations in BRCA1, HNPCC, and hereditary hemochromatosis genes. In addition, two national bodies, the NIH-DOE Task Force on Genetic Testing and the Secretary's Advisory Committee on Genetic Testing, have developed more general procedural and substantive requirements that should be satisfied before genetic tests are implemented in practice (Task Force on Genetic Testing 1997; Report of the Secretary's Advisory Committee on Genetic Testing 2000). One can speculate about why the professional and public response to genetic testing has been so much more restrained than it has been for other medical developments; contributing factors doubtless include the givenness of one's genetic makeup, fears about discrimination, the history of eugenics in the West, and the inextricable link between genetic information and reproductive testing and the potential desire to interfere with procreation. Whatever the reasons, the result is an approach to testing that increasingly is seen as a paradigm for the rest of medicine. This call for more empirical data and interpersonal reflection, however, does itself present additional challenges.

The first dilemma is the challenge of ensuring that patients understand the implications of genetic testing so that they can make informed decisions for themselves according to their own values about whether or not to proceed. As Jay Katz so eloquently demonstrated years ago in his book The Silent World of Doctor and Patient (Katz 1984), truly enabling patients to make their own choices is extremely difficult and probably would require a radical transformation of the practice of medicine. We have made little progress toward achieving this sort of shared decision making, even though it is relatively easy to understand the need to think about obtaining informed consent for invasive therapeutic interventions because these are unusual events in the lives of patients: Most people have vivid memories of surgeries and invasive radiologic procedures. By contrast, it will take even more to overcome the routinization of the simple blood test in the minds of both clinicians and patients.

A second question is whether society is truly committed to permitting people to proceed according to their own lights. The worry is not primarily that people will be forced or given incentives to accept therapy they do not want, although that is certainly possible. Instead, it is whether third-party payers will cover tests that people desire to obtain information about their risks or to justify seeking expensive and perhaps not demonstrably efficacious preventive interventions such as prophylactic surgery. Will a third-party payer actually be willing to spend $\$ 2000$ for a test to resolve a person's uncertainty? More to the point, because all of us ultimately bear the cost of health care, will you be willing to pay higher premiums or higher taxes or to receive smaller paychecks so that your employer can fund premiums that enable your neighbor to have an expensive test merely to allay his worries? Doubtless most people will try to use genetic information to improve their own health, but the goals and the costs of the health care payment and delivery systems will be challenged to the extent that individuals seek this information for other reasons.

One of the most pervasive concerns raised about genetic testing is the fear that the results will be used to 
deny access to health insurance. It is important to acknowledge that most people are not at immediate risk of losing their coverage if they find that they have a predisposing mutation because most people have coverage through their employer or a government program such as Medicaid or Medicare. Moreover, the Health Insurance Portability and Accountability Act (1996) made it somewhat easier for people to change jobs without losing their coverage or to enter the private insurance market. Nonetheless, to the extent that people need to purchase individual coverage, they rightly fear any test results that indicate that they may become ill in the future. In addition, the numerous efforts at both the state and federal levels to limit the use of genetic information in insurance underwriting demonstrate the difficulty of the task, due in no small part to the problems of deciding what is genetic and what is not. Legislatures have learned that simply prohibiting access to the results of DNA tests does not protect patients (Reilly 1997). DNA-based tests are still relatively uncommon, and in any event, a woman's family history of having numerous relatives with early onset breast and ovarian cancer reveals almost as much, if not more, about her risk of future disease as do her own test results for mutations in BRCA1. In fact, she could be mutation-negative but still at elevated risk if the cancers in her family were caused by mutations in a different gene or by environmental exposure. But if one excludes every health characteristic that is potentially influenced by genes from insurance underwriting, little risk information would remain for sellers of insurance to use, leaving them with the need to assume that everyone will suffer from an expensive illness in the near future. The whole debate surrounding genetic discrimination in access to health insurance demonstrates that the real question is not whether genetic information is somehow different from other information. Instead, the fundamental issue is whether health care coverage should be a matter of private business or employment benefit, as it is at present, or is something to which all people should be entitled as part of the social contract.

The social ramifications of genomics reach beyond the predictive and diagnostic to the therapeutic. At present, for example, pharmacogenomics is all the rage. The air is full of promises of targeted therapy, evoking images of a time when a test performed by using a simple chip will permit patients to get treatments that are more effective with fewer side effects. In theory, targeted intervention makes sense, and precedents exist for tailoring treatment. Clinicians determine antibiotic sensitivity of infectious organisms and evaluate malignancies for certain predictive characteristics; these characteristics are often caused by mutations, albeit sometimes acquired. Nonetheless, it is not yet clear whether developing targeted interventions for more common multifactorial disorders will be economically viable, and if so, how widely they will be made available. The first is a matter of whether the pharmaceutical industry believes there will be a big enough market to warrant the investment, particularly because tailoring therapy necessarily means fewer patients for any particular drug, and whether third-party payers are willing to pay the higher prices that doubtless will follow. The probable limitation of the benefits of pharmacogenomics to the fortunate few will exacerbate the problems of justice that already run throughout our health care system, in which many patients have access only to limited formularies, the contents of which are driven at least in part by the payer's ability to obtain a good price from a particular company.

A related issue that affects the future impact of genomics is the heated debate about gene patenting. Patents pervade health care delivery. Certainly the prospect of making money is a powerful driver of innovation, and virtually everyone would agree that the technology we have at present is the result of this incentive. Nonetheless several factors contribute to the air of concern that surrounds patenting genes. One is the enormous public investment that has gone into the Human Genome Project with its very public commitment of making the sequence available to everyone, literally on the day the sequence is deciphered. Patents privatize the products of this public investment. The government has been encouraging individuals, universities, and other entities to move the products of publicly funded research into the private sector ever since the enactment of Bayh-Dole (BayhDole Act 2000). The theory is that encouraging privatization and providing patent protection will ensure that the fruits of public research are made available for the care of patients, which after all was the primary reason for doing the research in the first place, but the transfer of the products of public money into private hands is becoming more and more obvious and troublesome.

Another source of disquiet about patents is the necessary involvement of particular patients in the discovery of disease genes; one cannot find a gene without access to DNA and phenotypic information from affected and unaffected individuals. Independent of the question of whether genes ought to be patentable at all or whether individuals whose DNA is used in this type of research should have some economic stake in the resulting products, patient-subjects and their families are growing more vocal about being "used". They complain that they participate in this type of research only to find that they are unable to obtain testing because some investigator or institution exercises patent rights. Dr. Judith Tsipis, speaking as a consumer on behalf of the National Tay-Sachs and Allied Diseases 
Association, made this point eloquently in her testimony last June before the Secretary's Advisory Committee on Genetic Testing regarding the limited availability of testing for Canavan disease (Highlights of the Fifth Meeting of the Secretary's Advisory Committee on Genetic Testing 2000). Concerns about limited access are likely to be even more acute for very rare disorders where the presence of patents, coupled with the burden of complying with the requirements of the Clinical Laboratory Improvement Act (CLIA), may mean that tests are never made available at all (Clinical Laboratory Improvement Amendments of 1988 [CLIA] 2000). These problems are not unique to geneticspharmaceutical and other products have to be validated with patients, rare diseases are frequently orphaned, and products will not be brought to market without the prospect of financial gain-but the dawning public recognition that being a research subject does not ensure access to the benefits of what is learned, especially when the researchers and commercial entities obtain substantial financial gains, may decrease subjects' willingness to participate. In the end, it may be necessary to reconsider the package of rights that currently accompany gene patents, perhaps moving to require licensing with statutorily-defined limits on the fees.

\section{The Implications of Genomics for Other Social Institutions and Fundamental Beliefs}

Greater understanding of genetics can also affect the way people regard themselves and others. The central nightmare is the specter of genetic determinism, which in its most extreme form asserts that people are entirely the product of their genes. Some of the metaphors currently applied to the human genome (the "book of life" being a prime example) foster this vision. A moment's thought reveals that this extreme position cannot be valid-even identical twins raised together differ from each other-but it is equally clear that genes do contribute to the individual's ultimate phenotype. The fact that most genes appear to be expressed only in the central nervous system suggests that even behavior is influenced by genes. The contribution of genes to function should lead us to ask two related, but separate, questions. The first is how to establish the roles that genes and environment play in the appearance of complex traits, a topic I leave to others.

The more important dilemma is deciding how we individually and as a society should respond to a greater understanding of the contributions of genes to human function. The social implications of knowing more about what genes do are potentially profound, in some instances going right to the heart of beliefs about personal responsibility, a conundrum that has occupied philosophers and theologians for millennia. A growing number of criminal defendants, for example, seek to avoid or decrease their punishment by arguing, "my genes made me do it." Our society is based on the premise that people should be responsible for their own actions. The criminal justice system and society in general have always had a hard time dealing with the notion that people with certain characteristics, such as insanity, youth, or mental retardation, can be excused from criminal responsibility for acts that harm others. The public often responds with outrage when a murderer successfully pleads insanity or is sent to juvenile court. Nonetheless, the existence of these defenses is based on a deeply held sense that people must have certain cognitive capacities before they can be subjected to the full penalties of the law. Efforts to assert genetic defenses will confront this tension between desires for retribution and deterrence and the nagging sense that certain people should not be held responsible for their acts.

The fact that this defense is allegedly based on science creates further reason for disquiet. Courts have for a long time struggled with the fear that triers of fact tend to see scientific evidence as particularly trustworthy, a reliance that is not always warranted. In a number of recent cases, criminal defense attorneys have sought to introduce evidence of family histories of violence or assays of monoamine oxidase levels, asserting their relevance to establishing genetic causes of the defendants' actions (Friedland 1997/98). The lawyers who pursue these strategies do so because they are obligated by canons of legal ethics to present the best possible defense for their clients. These attorneys often are also motivated by opposition to the death penalty and by beliefs that the criminal justice system is unfair in a number of ways. These socially appropriate reasons, however, do little to allay the concerns of those who believe that very little is known about genetic contributions to criminal behavior and who squirm at the use of what they see as pseudo-science.

Another fundamental issue that will arise from greater understanding of genetics is whether genetic differences will be seen as justification for treating some people less well than others. Using genetics to justify bigotry already occurs on the World Wide Web on the home pages of present-day eugenicists and white supremacists. Sadly, this is hardly surprising. A major theme of human history is individual and group desires to prove their "innate" superiority over others. Some people might even argue that this competitiveness is ingrained in humanity as a result of the evolutionary process.

Nonetheless, the social consequences of learning about what genes do are not preordained but rather are within our control. The history of employment discrimination law in the United States illustrates the potential to shape social responses. In the past, society passed laws forbidding discrimination on the basis of 
such factors as race, ethnicity, gender, pregnancy, age, and disability. Employers may well prefer to hire whomever they wish, but our lawmakers have chosen to mandate instead that some of the characteristics that differentiate us either should be irrelevant to employment (gender and race being good examples) or are simply costs that must be borne to level the playing field and to create the kind of inclusive society we want to live in, such as when accommodations must be made to permit individuals with physical disabilities to work.

Greater understanding of the contribution of genes to disease will present challenges such as these in almost every aspect of social life, ranging from employment, to education, to access to financial resources such as mortgages and life insurance. Should public transportation officials be permitted to fire employees who have mutations in the gene for Huntington disease, or should these agencies be required to rely instead on routine performance evaluations that would detect neurological problems before they cause any threat to the public? The central dilemma here is whether and when it is the genotype or the phenotype that matters. Regulatory bodies are already considering other questions about the use of genetic information in employment. Terri Seargent recently successfully asserted that her employer had fired her unlawfully because she was diagnosed with alpha-a-antitrypsin deficiency and, although asymptomatic, required expensive medication (Genetic Disease Organization 2000). The Equal Employment Opportunity Commission this year filed a suit to prevent a major railroad from performing DNA-based tests on its workers to see if they were predisposed to develop carpal tunnel syndrome (Lewin 2001).

Problems in other arenas might be presented were a child known to have familial hypercholesterolemia, a disease that almost always causes early mortality. Would it be appropriate for a college to deny her admission on the grounds that she would not live long enough to get any benefit from it? What about allowing her to matriculate but denying her financial aid? What if her parents decided not to invest in her education, but rather to send their other, unaffected child to school? Although all of the decisions affecting the life of the child with hypercholesterolemia might be viewed as troubling, our society is more likely to regulate the actions of the college than those of the parents. The deference for the latter is in keeping with widely held views of the family as relatively autonomous.

These questions evoke visions of Gattaca, a movie set in the near future in which the prediction (rendered within seconds of the protagonist's birth) that he was at risk for neurological disease, manic depressive disorder, attention deficit hyperactivity disorder, and heart disease, and had a life expectancy of 30.2 years meant that he was shunted into a life as a janitor. The plot of the movie, of course, is that our hero was able to triumph over this nightmare of genetic discrimination run rampant by adopting someone else's genetic identity. It did not hurt the course of the movie that the predictions of his disability and death were not accurate either, but clinicians know that that is the nature of prognostication.

In deciding how to respond to the geneattributable differences among us, we do not have the luxury of simply banning genetic discrimination. Our society values the ability to excel in any number of areas that are influenced by genes. One would be hard pressed to say that the National Basketball Association should exclude someone like Michael Jordan in favor of someone with little or no athletic ability or that airlines should be forced to hire a pilot who has a genetically based, poorly controlled arrhythmia that predisposes him to sudden death. Instead the challenge is, as it has always been, to decide which differences should make a difference. Confronting the implications of genetics requires consideration of fundamental notions of justice and of the type of society we desire.

The most far-reaching effects of having the rough draft of the human genome sequence, as well as that of other organisms, are what the sequence says for the role of human beings in the larger scheme of life. The extraordinary homology among the genes of different organisms is, of course, great news for biomedical research. If other animals had completely different genomes from ours, it would be impossible to extrapolate results from these organisms to the human. The extent of the observed homologies is also the most powerful evidence available against the rather surprising reemergence of those who would require the teaching of creation science to our children, sometimes to the exclusion of the theory of evolution (Johnson 1995).

Even more remarkable are the facts that all humans share $>99.9 \%$ of their sequence, that all humanity is descended from a single group of founders, that more sequence variation exists within ethnic groups than between them, and that race does not exist as a genetic entity (or, put another way, that there are no genes for "race"). These facts are powerful evidence of the unity of humanity. One can only hope that a way can be found to use this new understanding to reduce the ethnic hatred that afflicts the world. It would be sweet indeed if the world were brought closer together by the double helix.

The growing understanding of genomics affects society in other ways that have not been addressed in this essay, but enough has already been discussed to make the point clear. Seeing the world through the lens of genetics has the power to change how we regard one another, how we think about such fundamental 
precepts as justice, and how we understand ourselves and our own actions. The challenge, acknowledged by James Watson more than a decade ago and enthusiastically embraced by Francis Collins in his support for the ELSI Program of the National Human Genome Research Institute and by Ari Patrinos in the Department of Energy, is to keep what we see through this lens in perspective and to try as best we can to ensure that this powerful knowledge is used to benefit all people.

\section{ACKNOWLEDGMENTS}

This commentary was supported in part by funding from 1 R01 HG01974-01. I thank Jay Clayton and Marie Griffin for their insightful comments on earlier drafts.

\section{REFERENCES}

Bayh-Dole Act. 2000. 35 U.S.C. §§ 200-212.

Clinical Laboratory Improvement Amendments of 1988 (CLIA). 2000. Public Law 100-578, amending 42 USCA §§ 201, 263a.

Friedland, S.I. 1997/98. The criminal law implications of the Human Genome Project: Reimaging a genetically oriented criminal justice system. Kentucky Law Journal 86: 303-366.

Genetic Disease Organization part of Health and Human Services ceremony 2000. http://www.alpha1.org/alliance/hhs12-00.htm
Health Insurance Portability and Accountability Act of 1996. 2000. Public Law 104-191 (HIPAA), codified at 26 U.S.C. \$§ 9801-9806, 29 U.S.C §§_1162-1167, 1181-1191c, 42 U.S.C. § 300gg.

Highlights of the fifth meeting of the Secretary's Advisory Committee on Genetic Testing. June 5-7, 2000. Washington, D.C. http://www4.od.nih.gov/oba/highlights62000.htm

Johnson, P.E. 1995. Reason in the balance: The case against naturalism in science, law \& education. InterVarsity Press, Downers Grove, IL

Katz, J. 1984. The silent world of doctor and patient. Free Press, New York.

Lewin, T. 2001. Commission sues railroad to end genetic discrimination in work injury cases. New York Times A7: 2/10-01.

Reilly, P. 1997. In Genetic secrets: Protecting privacy in the genetic era (ed. M.A. Rothstein), pp. 369-391. Yale University Press, New Haven.

Report of the Joint NIH/DOE Committee to Evaluate the Ethical, Legal, and Social Implications Program of the Human Genome Project. 2000. http://www.nhgri.nih.gov:80/Policy_and_public_affairs/Elsi/ elsi_recs.html

Report of the Secretary's Advisory Committee on Genetic Testing. 2000. Enhancing the oversight of genetic tests: Recommendations of the SACGT. http://www4.od.nih.gov/oba/

FINAL\%20SACGTreport713700 correctedpage27.htm

Rifkin, J. 1984. Algeny. Penguin, New York.

Task Force on Genetic Testing. 1997. Promoting safe and effective genetic testing in the United States: Final report of the Task Force on Genetic Testing (ed. N.A. Holtzman and M. Watson). Johns Hopkins University Press, Baltimore.

\section{Genome Research}




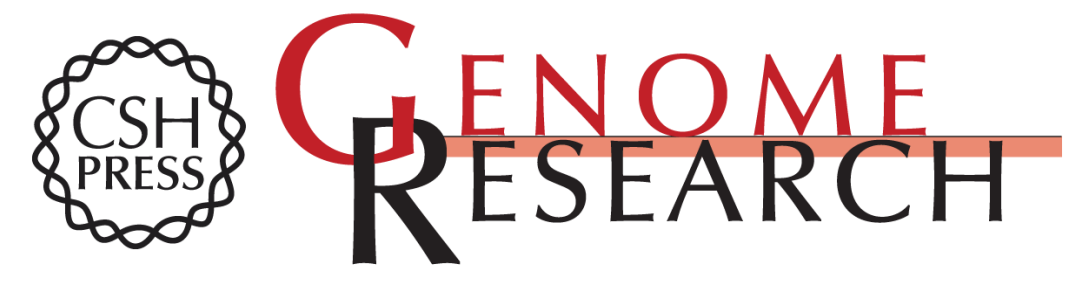

\section{Through the Lens of the Sequence}

Ellen Wright Clayton

Genome Res. 2001 11: 659-664

Access the most recent version at doi:10.1101/gr.187801

\section{License}

Email Alerting Receive free email alerts when new articles cite this article - sign up in the box at the Service top right corner of the article or click here.

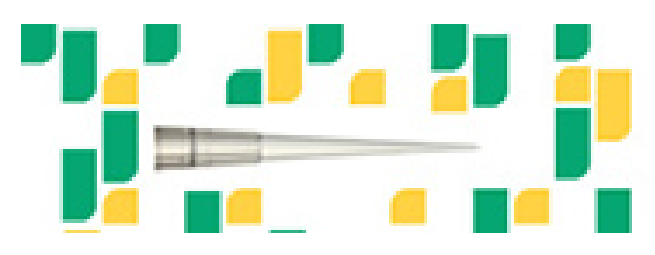

To subscribe to Genome Research go to: https://genome.cshlp.org/subscriptions 